\title{
Profile of micronucleus frequencies and nuclear abnormalities in different species of electric fishes (Gymnotiformes) from the Eastern Amazon
}

\author{
Karina Motta Melo ${ }^{1 *}$, Ingrid Reale Alves ${ }^{1 *}$, Julio Cesar Pieczarka ${ }^{1}$, José Augusto de Oliveira David ${ }^{2}$, \\ Cleusa Yoshiko Nagamachi ${ }^{1}$ and Cesar Koppe Grisolia ${ }^{3}$ \\ ${ }^{1}$ Laboratório de Citogenética, Instituto de Ciências Biológicas, Universidade Federal do Pará, Belém, \\ PA, Brazil. \\ ${ }^{2}$ Departamento de Biologia, Universidade Federal do Espírito Santo, Vitória, ES, Brazil. \\ ${ }^{3}$ Laboratório de Genética Toxicológica, Instituto de Ciências Biológicas, Universidade de Brasília, \\ Brasília, DF, Brazil.
}

\begin{abstract}
The frequency of spontaneous micronucleus (MN) formation in fish species needs to be determined to evaluate their usefulness for genotoxic biomonitoring. The definition of a good bioindicator takes into account the current knowledge of its metabolic traits as well as other factors including its feeding behavior and relationship to the environment. In this study, we compared the basal frequencies of micronucleated erythrocytes and nuclear abnormalities (NA) among different species of the fish Order Gymnotiformes (Rhamphichthys marmoratus, Steatogenys elegans, Sternopygus macrurus, Parapteronotus hasemani, Gymnotus mamiraua, Gymnotus arapaima, Brachyhypopomus beebei, Brachyhypopomus n. sp. BENN) sampled in several localities of the Eastern Amazon. A baseline of MN and NA frequency in these fish was determined, enabling the identification of potentially useful species as models for genotoxicity studies. Only one impacted sample collected at a site in the River Caripetuba showed a significant number of NAs, which may be due to the release of wastewater by neighbouring mining industries and by the burnt fuel released by the small boats used by a local community. Our results may provide support for further studies in areas of the Eastern Amazon affected by mining, deforestation and other anthropogenic activities.
\end{abstract}

Keywords: biomonitoring, genotoxicity, Gymnotiformes, Amazon region, fish erythrocytes.

Received: February 13, 2013; Accepted: May 17, 2013.

The micronucleus assay $(\mathrm{MN})$ has been widely used to detect clastogenic and aneugenic compounds in water. Micronucleus in peripheral erythrocytes of fishes are a suitable biomarker for genotoxic studies and for testing the pollution of aquatic ecosystems, due to easy sampling and high sensitivity (Carrasco et al., 1990, Fenech, 2000, Bolognesi and Hayashi, 2011). In fish, erythrocyte MN and Nuclear Abnormalities (NAs) also appear spontaneously and their frequencies may be season-dependent (Bolognesi et al., 2006). Large-scale biomonitoring programs for genotoxic compounds in aquatic environments require biomarkers that are technically easier and quicker to analyze than cytogenetic analysis or DNA damage assays. Thus, the evaluation of $\mathrm{MN}$ baseline frequencies can provide information on the level of MN caused by environmental and genetic factors and may be helpful to monitor degradation

Send correspondence to Cesar Koppe Grisolia. Departamento de Genética e Morfologia, Instituto de Ciências Biológicas, Universidade de Brasília, 70910-900 Brasilia, DF, Brazil. E-mail grisolia@unb.br.

*These authors contributed equally to this paper. processes in water bodies caused by anthropogenic activities (De Lemos et al., 2001; Surowy et al., 2011).

In addition to the formation of $\mathrm{MN}$ and NAs, spontaneous breaks in DNA in various organisms may result from intrinsic errors during DNA metabolism, without the influence of external agents. This damage may be enhanced by the exposure to mutagenic and genotoxic agents, which increase breaks or genetic recombination, giving rise to mutations and potential neoplasms (Ribeiro et al., 2003). Fish are suitable organisms for the in situ investigation of aquatic pollutants, as well as for biomonitoring. Among their advantages as bioindicators are that they respond to the presence of pollutants in ways similar to other vertebrates, including humans, in terms of induction of damage to genetic material. They also play different roles in the trophic web, activating xenobiotics through the P450dependent oxidative metabolism, as do mammals (Goksoyr et al., 1991; Al-sabti and Metcalfe, 1995).

Fish of the Order Gymnotiformes are widely distributed in the Neotropical region (Albert and Sand-Crampton, 2005). They are known as electric fishes because they have 
electrical receptors and transmitters involved in intraspecific communication (Kramer, 1996). The frequency of their electric discharges is very stable in constant environmental conditions, but significant changes in discharge occur in response to changes in water quality (Thomas et al., 1996), which makes them useful as bioindicators. Few studies have investigated mutagenic and genotoxic damage in Gymnotiformes. In this work we analyzed the frequency of spontaneous $\mathrm{MN}$ and NA formation in fishes of the Order Gymnotiformes aiming to evaluate their sensitivity as bioindicators and usefulness for further genotoxicity and mutagenicity studies and biomonitoring programs.

The Gymnotiformes fishes were collected in several localities in the Eastern Amazon without anthropogenic impact: Mamirauá (a sustainable community $\left.03^{\circ} 01^{\prime} 41.8^{\prime \prime} \mathrm{S} ; 064^{\circ} 51^{\prime} 16.6^{\prime \prime} \mathrm{W}\right)$, the Municipality of Tefé - Amazon River (0307’09.4” S; 06447’24.3” W), Muaná - Marajó Island $\left(01^{\circ} 15^{\prime} 38.2^{\prime \prime} \mathrm{S}\right.$; $\left.049^{\circ} 28^{\prime} 42.2^{\prime \prime} \mathrm{W}\right)$ and Curralinho - Marajó Island $\left(01^{\circ} 45^{\prime} 49.8^{\prime \prime} \mathrm{S}\right.$; $049^{\circ} 43^{\prime} 53.4^{\prime \prime} \mathrm{W}$ ), and in an impacted area of the Caripetuba River - Abaetetuba (013’23.49” S; 048 $\left.55^{\prime} 33^{\prime \prime} \mathrm{W}\right)$, that receives crude wastewater from mining. Eight species of fish from the Order Gymnotiformes were collected: Rhamphichthys marmoratus $(\mathrm{n}=10)$, Steatogenys elegans $(\mathrm{n}=6)$, Sternopygus macrurus $(\mathrm{n}=12)$, Parapteronotus hasemani $(\mathrm{n}=5)$, Gymnotus mamiraua $(\mathrm{n}=9)$, Gymnotus arapaima $(\mathrm{n}=7)$, Brachyhypopomus beebei $(\mathrm{n}=7)$, and Brachyhypopomus $\mathrm{n}$. sp. BENN ( $=5)$. Collections were performed with the authorization of the Instituto Brasileiro do Meio Ambiente (IBAMA, permit 13248-1, registration 242396). Peripheral blood samples were smeared on glass slides, dried at room temperature, fixed in ethanol for $10 \mathrm{~min}$, hydrolyzed in HCL (1N) for $5 \mathrm{~min}$, and stained with Giemsa. 3000 erythrocytes per fish were scored at 1,000X magnification. The criteria for the identification of fish erythrocytes containing MN were as follows: (a) the MN had to be smaller than one-third of the main nuclei; (b) the MN could not touch the main nuclei; (c) the MN could not be refractive and should have the same color and staining intensity as the main nuclei. Nuclear abnormalities were considered as blebbed, lobed, notched, binucleated and vacuolized. MN and NAs were analyzed with the non-parametric test of Kruskal-Wallis, with significance set at $5 \%$.

The mean frequencies of MN, NAs, standard deviation and sample size for each species of Gymnotiformes from Mamirauá are shown in Table 1. The obtained values for the baseline rate of MN and NA for each species collected at this site showed very low levels (Table 1), and no significant statistical differences were observed among them $(p>0.05)$. MN frequencies were also very low in other municipalities, but samples from Abaetetuba showed a higher frequency of NAs $(\mathrm{p}<0.05)$ (Table 2). The Caripetuba River - Abaetetuba is under the influence of a bauxite mining region of many aluminum industries. The mining operation and its waste disposal into the Caripetuba River causes degradation of the water quality. As this region is also subject to the tidal regime, this may be

Table 1 - Frequencies of MNs and NAs in different species of the order Gymnotiformes sampled in the sustainable community of Mamirauá.

\begin{tabular}{lcc}
\hline Species & Mean and standard deviation of MN & Mean and standard deviation of MN \\
\hline Rhamphichthys marmoratus $(\mathrm{n}=10)$ & $0.013 \pm 0.023$ & $0.017 \pm 0.023$ \\
Steatogenys elegans $(\mathrm{n}=6)$ & $0.006 \pm 0.015$ & 0 \\
Sternopygus macrurus $(\mathrm{n}=12)$ & $0.019 \pm 0.030$ & $0.134 \pm 0.181$ \\
Parapteronotus hasemani $(\mathrm{n}=5)$ & $0.033 \pm 0.023$ & $0.146 \pm 0.132$ \\
Gymnotus mamiraua $(\mathrm{n}=9)$ & $0.007 \pm 0.022$ & $0.037 \pm 0.045$ \\
Gymnotus arapaima $(\mathrm{n}=7)$ & $0.005 \pm 0.012$ & $0.058 \pm 0.089$ \\
Brachyhypopomus beebei $(\mathrm{n}=7)$ & $0.023 \pm 0.030$ & $0.083 \pm 0.129$ \\
Brachyhypopomus $n$. $\operatorname{sp}$. BENN $(\mathrm{n}=5)$ & $0.164 \pm 0.258$ & $0.158 \pm 0.142$ \\
\hline
\end{tabular}

Table 2 - Frequencies (mean and standard deviation) of MNs and NAs in Sternopygus macrurus from different localities of the Eastern Amazon.

\begin{tabular}{lcc}
\hline Locality & Mean \pm SD of MN & Mean \pm SD of NA \\
\hline Sustainable Community of Mamirauá $(\mathrm{n}=12)$ & $0.019 \pm 0.030$ & $0.134 \pm 0.181$ \\
Muaná - Marajó Island $(\mathrm{n}=4)$ & $0.017 \pm 0.019$ & $0.042 \pm 0.042$ \\
Curralinho - Marajó Island $(\mathrm{n}=9)$ & $0.013 \pm 0.030$ & $0.151 \pm 0.078$ \\
Tefé - Amazon River $(\mathrm{n}=5)$ & $0.077 \pm 0.106$ & $0.249 \pm 0.370$ \\
Caripetuba River - Abaetetuba $(\mathrm{n}=14)$ & $0.048 \pm 0.065$ & $0.504 \pm 0.241^{*}$ \\
\hline
\end{tabular}

*Statistically different from Mamirauá (AM) and Muaná (Marajó Island-PA) (Kruskal-Wallis, p <0.05). 
responsible for the fluctuating levels of pollutants discharged and present in the aquatic environment. Furthermore, the Caripetuba River is characterized by an intense traffic of boats by a local community. The burnt fuel of these boats contains a series of compounds capable of inducing DNA damage, which may influence the formation of NA found in specimens collected in the river. This analysis was carried out only in S. macrurus, because this is the most abundant species and it was found at all sampled sites. The genotoxicity studies with fish in the literature use the baseline MN frequency in the control groups as reference values. Considering laboratory and field studies, the baseline MN frequency showed very low levels (Table 3). The same analysis was carried out for nuclear abnormalities (Table 3).

Some fish species are less sensitive than others as bioindicators of genotoxicity in the water. Many factors may be responsible for these differences, such as metabolism, DNA repair efficiency, defense mechanisms and trophic level in the food chain (Grisolia et al., 2009, Bolognesi and Hayashi, 2011). Field studies have reported higher variability in baseline MN frequency compared with laboratory studies. Several factors may explain this variability, such as genetic heterogeneity in wild populations, variability in the water environment, seasonal effects, variations in physico-chemical parameters of the water, food availability, and other stressor agents (Bolognesi et al., 2006; Bolognesi and Hayashi, 2011).
Colossoma macropomun, known as tambaqui, is the largest Characiform fish in the Amazon River. In laboratory conditions, it presented a basal MN frequency of $2.4 \%$ (Rocha et al., 2011). In a study carried out by Grisolia et al. (2009) in a tropical eutrophic lake, the baseline MN frequencies and NAs were scored for different fish species according to their food habits (omnivorous, detritivorous, piscivorous, algivorous and herbivorous). Top-chain and detritivorous species presented a higher MN baseline frequency, probably due to the bioaccumulation and/or biomagnification of toxic contaminants present in that lake (Table 3). Porto et al. (2005) evaluated the MN frequencies in peripheral erythrocytes of three fish species from the Solimões River (central Amazon): Prochilodus nigricans (detritivorous), Mylossoma duriventris (omnivorous) and Hoplias malabaricus (piscivorous). The mean frequencies of MN observed were $1.0 \%, 1.0 \%$ and $0.6 \%$, respectively. These values were considered very low, associated with the fact that there was not any kind of anthropogenic activities at the sampled sites. Compared with the Madeira River (southwestern Amazon), highly impacted by mercury due to gold-mining, the MN means for these three fish species were $3.8 \%, 3.7 \%$ and $17.6 \%$, respectively, significantly higher than in the Solimões River. H. malabaricus is also a carnivore top-chain species and presented the highest level of MN. Table 3 shows native fish species commonly found in South American rivers, such as $P$. nigricans, $H$. malabaricus, A. bimaculatus, M. duriventris, A.

Table 3 - Baseline MN frequencies and nuclear abnormalities obtained from control groups in laboratory and field studies.

\begin{tabular}{|c|c|c|c|c|}
\hline Species & Food habits & $\begin{array}{l}\text { Baseline MN } \\
\text { frequencies (\%) }\end{array}$ & $\begin{array}{l}\text { Baseline nuclear } \\
\text { abnormalities (\%) }\end{array}$ & References \\
\hline Prochilodus nigricans & Detritivorous & 0.01 & - & Porto et al. (2005) \\
\hline Mylossoma duriventris & Omnivorous & 0.01 & - & Porto et al. (2005) \\
\hline Hoplias malabaricus & Piscivorous & 0.006 & - & Porto et al. (2005) \\
\hline Astyanax bimaculatus & Omnivorous & 0.013 & - & Pantaleão et al. (2006) \\
\hline Hopliasmalabaricus & Piscivorous & 0.033 & - & Pantaleão et al. (2006) \\
\hline Astyanax jacuhiensis & Omnivorous & 0.0210 .019 & -- & De Lemos et al. (2008) \\
\hline Oreochromis niloticus & Omnivorous/ Detritivorous & 0.05 & - & Rocha et al. (2009) \\
\hline Steindachnerina insculpita & Omnivorous/ Detritivorous & 0.70 & 3.27 & Grisolia et al. (2009) \\
\hline Geophagus brasiliensis & Omnivorous & 0.86 & 5.86 & Grisolia et al. (2009) \\
\hline Oreochromis niloticus & Omnivorous/ Detritivorous & 0.87 & 3.29 & Grisolia et al. (2009) \\
\hline Cyprinus carpio & Algivorous & 0.94 & 5.51 & Grisolia et al. (2009) \\
\hline Astyanax bimaculatus & Omnivorous & 1.13 & 12.2 & Grisolia et al. (2009) \\
\hline Hoplia smalabaricus & Piscivorous & 1.80 & 1.89 & Grisolia et al. (2009) \\
\hline Cichla temensis & Piscivorous & 1.86 & 9.15 & Grisolia et al. (2009) \\
\hline Oreochromis niloticus & Onmivorous/ Detritivorous & 0.65 & 2.20 & Souza and Fontanetti (2006) \\
\hline Cyprinus carpio & Algivorous & 0.40 & - & Buschini et al. (2004) \\
\hline Prochilodus lineatus & Detritivorous & 0.00 & - & Cavalcante et al. (2008) \\
\hline Oncorhynchus mykiss & Onmivorous & 0.18 & - & Ayllón and Garcia-Vasquez (2001) \\
\hline Barbus plebejus & Benthic feeder & 0.50 & - & Minissi and Rizzoni (1996) \\
\hline
\end{tabular}


jacuhiensis, S. sculpita, G. brasiliensis, C. temensis and $P$. lineatus. The basal $\mathrm{MN}$ interspecies variability ranged from $0 \%$ to $1.86 \%$. Non-native species, such as $C$. carpio (common carp), O. niloticus (tilapia), B. plebejus and O. mykiss (rainbow trout) are widely used around the world for laboratory $\mathrm{MN}$ testing. Among these four non-native species the $\mathrm{MN}$ variability ranged from $0.05 \%$ to $0.94 \%$. On the other hand, this MN baseline frequency may show different values depending on laboratory scoring criteria and biotic factors, such as age, sex, feed, genetic make-up, etc (Bolognesi and Hayashi, 2011). Zúñiga-Gonzáles et al. (2000) determined the spontaneous MN in peripheral blood erythrocytes from 54 species including mammals, reptiles and birds. The authors found that some groups of species had more spontaneous MN than others. NAs are considered by different authors to result from cytotoxicity or from genotoxicity. Nevertheless, Ayllón and Garcia-Vasquez (2001) demonstrated a direct relationship between MN induction and an increased level of NAs in rainbow trout after exposure to different clastogens, and recommended that NAs should be considered also as indicators of genotoxicity, even though their formation mechanisms are not totally understood.

This study showed the importance of establishing the basal MN frequency and the nuclear abnormalities in different native fish species in order to provide in situ biological indicators for biomonitoring anthropogenic impacts on the Amazon Basin. Our results, obtained from different species of the Order Gymnotiformes, may provide support for further studies in the eastern Amazon in regions affected by mining, deforestation and other anthropogenic activities.

\section{Acknowledgments}

We thank the Fundação de Amparo à Pesquisa do Estado do Pará (FAPESPA) for a grant to Julio Cesar Pieczarka (PRONEX, TO 011/2008) and to José Augusto de Oliveira David (DCR Scholarship, TO 008/2008), and CNPq and UFPA for financial support. We thank the IDSM (Instituto de Desenvolvimento Sustentável Mamirauá) for logistic support with the collections. Collections were authorized by IBAMA (Instituto Brasileiro do Meio Ambiente) permit 13248-1 (IBAMA Registration 242396).

\section{References}

Albert J and Sand-Crampton WGR (2005) Diversity and phylogeny of Neotropical electric fishes (Gymnotiformes). In: Bullock TE, Hopkins CD, Popper AN and Fay R (eds) Electroreception. Cornell University Press, Ithaca, pp 360-403.

Al-sabti K and Metcalfe CD (1995) Fish micronuclei for assessing genotoxicity in water. Mutat Res 343:121-135.

Ayllón F and Garcia-Vasquez E (2001) Micronuclei and other nuclear lesions as in rainbow trout. Oncorhynchus mykiss. Ecotoxicol Environ Saf 49:221-225.
Bolognesi C and Hayashi M (2011) Micronucleus assay in aquatic animals. Mutagenesis 26:205-213.

Bolognesi C, Perrone E, Roggieri P, Pampanin D and Sciutto A (2006) Assessment of micronuclei induction in peripheral erythrocytes of fish exposed to xenobiotics under controlled conditions. Aquat Toxicol 78:93-98.

Buschini A, Martino A, Gustavino B, Monfrinotti M, Poli P, Rossi C, Santoro M, Dörr AJM and Rizzoni M (2004) Comet assay and micronucleus test in circulating erythrocytes of Cyprinus exposed in situ to lake waters treated with disinfectants for potabilization. Mutat Res 557:119-129.

Carrasco KR, Tilbury KL and Myers MS (1990) Assessment of the piscine micronucleus test as an in situ biological indicator of chemical contaminant effects. Can Aquat Sci 47:2123-2136.

Cavalcante DGSM, Martinez CBR and Sofia SH (2008) Genotoxic effects of Roundup on the fish Prochilodus lineatus. Mutat Res 655:41-46.

De Lemos CT, Rodel PM, Terra NR and Erdtmann B (2001) Evaluation of basal micronucleus frequency and hexavalent chromium effects in fish erythrocytes. Environ Toxicol Chem 20:1320-1324.

Fenech M (2000) The in vitro micronuclei technique. Mutat Res 455:81-95.

Ferraris CJ (2003) Checklist of the Freshwater Fishes of South and Central America. Porto Alegre, EDIPUCRS, 742 pp.

Goksoyr A, Andersson T, Buhler DR, Stegenman JJ, Williams DE and Forlin L (1991) Immunochemical cross-reactivity of beta-naphthoflavone-inducible cytochrome P450 (P450IA1) in liver microsomes from different fish specie and rat. Fish Physiol Chem 9:1-13.

Grisolia CK, Rivero CLG, Starling FLRM, Silva ICR, Barbosa AC and Dorea JG (2009) Profile of micronucleus frequencies and DNA damage in different species of fish in a eutrophic tropical lake. Genet Mol Biol 32:138-143.

Kramer B (1996) Electroreception and Communication in Fishes. In: Rathmayer W (ed) Progress in Zoology, vol. 42. Gustav Fischer, Stuttgart, 131p.

Minissi S and Rizzoni M (1996) Micronucleus test in erythrocytes of Barbus plebejus (Teleostei Pisces) from two natural environments: A bioassay for the in situ detection of mutagens in freshwater. Mutat Res 367:245-251.

Pantaleão SM, Alcântara AV, Alves JPH and Spanó MA (2006) The piscine micronucleus test to assess the impact of pollution on the Japaratuba river in Brazil. Environ and Mol Mutagen 47:219-224.

Porto JIR, Araujo CSO and Feldberg E (2005) Mutagenic effects of mercury pollution as revealed by micronucleus test on three Amazonian fish species. Environ Res 97:287-292.

Ribeiro LR (2003) Mutagênese Ambiental. Ulbra Editora, Canoas, $355 \mathrm{pp}$

Rocha PS, Luvizotto GL, Kosmehl T, Böttcher M, Storch V, Braunbeck T and Hollert H. (2009) Sediment genotoxicity in the Tietê River (São Paulo, Brazil): In vitro comet assay vs. in situ micronucleus assay studies. Ecotoxicol Environ Saf 72:1842-1848.

Rocha CAM, Cunha LA, Pinheiro RHS, Bahia MO and Burbano RMR (2011) Studies of micronuclei and other nuclear abnormalities in red blood cells of Colossoma macropomum exposed to methylmercury. Genet Mol Biol 34:694-697. 
Souza TS and Fontanetti CS (2006) Micronucleus test and observation of nuclear alterations in erythrocytes of Nile tilapia exposed to waters affected by refinery effluent. Mutat Res 605:87-93.

Surowy H, Rinckleb A, Luedeke M, Stuber M, Wecker A, Varga D, Maier C, Hoegel J and Vogel W (2011) Heritability of baseline and induced micronucleus frequencies. Mutagenesis $26: 111-117$.

Thomas M, Florion A, Chrétien D and Terver D (1996) Real-time biomonitoring of water contamination by cyanide based on analyses of the continuous electrical signal emitted by the tropical fish, Apteronotus albifrons. Water Res 30:3083-3091.

Zúñiga-Gonzáles G, Torres-Bugarin O, Luna-Aguirre J, Gonzáles-Rodrígues A, Zamora-Perez A, Gómesz-Meda BC, Ventura-Aguilar AJ, Ramos-Ibarra ML, Ortíz GG and Gallegos-Arreola MP (2000) Spontaneous micronuclei in peripheral blood erythrocytes from 54 animal species (mammals, reptiles and birds): Part two. Mutat Res. 467:99-103.

Associate Editor: Carlos R. Machado

License information: This is an open-access article distributed under the terms of the Creative Commons Attribution License, which permits unrestricted use, distribution, and reproduction in any medium, provided the original work is properly cited. 